Boecker, E. A., \& Snell, E. E. (1972) Enzymes, 3rd Ed. 6, 245-248.

Dixon, H. B. F., \& Fields, R. (1972) Methods Enzymol. 25, 409-419.

Fisher, E. H., Forrey, A. W., Hedrick, J. L., Hughes, R. G., Kent, A. B., \& Krebs, E. G. (1963) Chem. Biol. Aspects Pyridoxal Catal., Proc. Symp. Int. Union Biochem. 1962, 554.

Gaal, A., \& Neujahr, H. Y. (1979) J. Bacteriol. 137, 13-21.

Gaal, A., \& Neujahr, H. Y. (1980) Electrophoresis '79, Proc. Int. Conf., 529-538.

Glazer, A. N., Delange, R. J., \& Sigman, D. S. (1975) Lab. Tech. Biochem. Mol. Biol. 4 (Part I), 131-134.

Habeeb, A. F. S. A. (1966) Anal. Biochem. 14, 328-336.

Hunter, M. I., \& Ludwig, M. L. (1972) Methods Enzymol. $25,585-596$.

Kjellên, K. G., \& Neujahr, H. Y. (1979) Biotechnol. Bioeng. $21,715-719$.
Levy, H. M., Leber, P. D., \& Ryan, E. M. (1963) J. Biol. Chem. 238, 3654-3659.

Neujahr, H. Y. (1976) Flavins Flavoproteins, Proc. Int. Symp., 5th, 1975, 161-168.

Neujahr, H. Y., \& Varga, J. (1970) Eur. J. Biochem. 13, 37-44.

Neujahr, H. Y., \& Gaal, A. (1973) Eur. J. Biochem. 35, 386-400.

Neujahr, H. Y., \& Gaal, A. (1975) Eur. J. Biochem. 58, 351-357.

Neujahr, H. Y., \& Gaal, A. (1978) Proc. Int. Symp. Yeasts, 4th, Abstr. No. SVI 16.

Neujahr, H. Y., \& Kjellên, K. G. (1978) J. Biol. Chem. 253, 8835-8840.

Neujahr, H. Y., Lindsjö, S., \& Varga, J. (1974) Antonie van Leewenhoek 40, 209-216.

Stark, G. R. (1972) Methods Enzymol. 25, 579-584.

\title{
Mitochondrial Hexokinase of Rat Hepatoma Cells in Culture: Solubilization and Kinetic Properties ${ }^{\dagger}$
}

\author{
Ernesto Bustamante ${ }^{\ddagger}$ and Peter L. Pedersen*
}

ABSTRACT: The highly glycolytic hepatoma cell line $\mathrm{H}-91$ is characterized by a high hexokinase activity relative to rat liver; $50 \%$ of this activity is associated with the mitochondrial fraction [Bustamante, E., \& Pedersen, P. L. (1977) Proc. Natl. Acad. Sci. U.S.A. 74, 3735-3739]. Treatment of mitochondria from this cell line with adenosine 5 -triphosphate (ATP) or glucose 6-phosphate solubilizes bound hexokinase activity. Solubilization of the enzyme by ATP results in a six- to sevenfold purification. Free ATP, unchelated by $\mathrm{Mg}$ ions, induces the release of the enzyme from the membrane, whereas the MgATP complex is ineffective. Ethylenediaminetetraacetic acid (EDTA) fails to release mitochondrial hexokinase indicating that the enzyme is not attached to the membrane by divalent cations. Energization of mitochondria is not required for ATP to induce solubilization of bound hexokinase. This is evidenced by (a) the ability of the nonhydrolyzable ATP analogue adenylyl imidodiphosphate to solubilize the enzyme,

U tter et al. (1945) first observed that the hexokinase (ATP:D-hexose 6-phosphotransferase, EC 2.7.1.1) activity found in homogenates of rat brain is markedly reduced upon centrifugation. This observation led Crane \& Sols (1953) to examine the hexokinase activities of rat tissues, where they found that $50 \%$ or more of the total cell hexokinase activity

\footnotetext{
${ }^{\dagger}$ From the Laboratory for Molecular and Cellular Bioenergetics, Department of Physiological Chemistry, The Johns Hopkins University School of Medicine, Baltimore, Maryland 21205. Received April 4, 1980. This work was supported by a U.S. Public Health Service Grant (CA 10951) from the National Cancer Institute. E.B. was supported by fellowships from the Lilly Research Laboratories, the Du Pont Co., and the Ford Foundation.

${ }^{\ddagger}$ Present address: Department of Physiological Sciences, Universidad Cayetano Heredia, Apartado 5045, Lima 100, Peru.
}

(b) the inability of uncouplers and inhibitors of oxidative phosphorylation to either solubilize or prevent the release of mitochondrial hexokinase, and (c) the inability of atractyloside to solubilize or prevent the release of bound hexokinase. The bound and the ATP-solubilized forms of mitochondrial hexokinase from H-91 hepatoma cells are kinetically different. When membrane bound, the enzyme has a significantly higher apparent affinity $\left(K_{\mathrm{m}}=0.25 \mathrm{mM}\right)$ for its substrate $\mathrm{MgATP}$ than when solubilized $\left(K_{\mathrm{m}}=1.2 \mathrm{mM}\right)$. Free ATP acts as a competitive inhibitor of mitochondrial hexokinase. Both the membrane-bound and the solubilized forms of mitochondrial hexokinase have about the same apparent affinity for glucose ( $K_{\mathrm{m}}=56$ and $83 \mu \mathrm{M}$, respectively). The experiments reported here provide the first description of the properties and the nature of binding of mitochondrial hexokinase from a tumor cell line growing in tissue culture.

of brain, heart, kidney, and intestinal mucosa is associated with an unidentified $18000 \mathrm{~g}$ sediment. Johnson (1960) was able to identify the particulate enzyme of brain homogenates as mitochondrially bound. Studies of Asc et al. (1955) and Wu \& Racker (1959) were among the first to demonstrate that in some cancer cells a large fraction of the total cell hexokinase activity is membrane bound. These observations have now been extended to other systems. For recent reviews, see Wilson \& Flegner (1977); Pedersen (1978); also see Rose \& Warms (1967); Bustamante \& Pedersen (1977); Graziani (1977); Gellerich \& Augustin (1977). Perhaps the first really clear demonstration of an association of hexokinase with mitochondria was presented in a now classical paper by Rose \& Warms (1967). They also showed that the hexokinase reactant $\mathrm{ATP}^{1}$ and the product glucose 6-phosphate can specifically 
solubilize the enzyme from the mitochondria, confirming results by Hernandez \& Crane (1966).

Hexokinase is now known to be attached to the external face of the outer membrane of mitochondria [for a review, see Colowick (1973)]. Although the nature of the binding as well as its physiological meaning is not yet understood, several views have been advanced as to why hexokinase is located on the outer mitochondrial membrane (Bessman, 1966; Rose \& Warms, 1967; Wilson, 1968; Koobs, 1971; Gots \& Bessman, 1974; Bustamante \& Pedersen, 1977; Bessman et al., 1978; Bustamante et al., 1978). Among these views is the theory proposed by Bessman and co-workers (Bessman, 1966; Gots \& Bessman, 1974; Bessman et al., 1978) which states that insulin may promote the binding of hexokinase to mitochondria in order to produce an increase in the respiratory control (increased efficiency of oxidative phosphorylation) and so facilitate transfer of energy to insulin-dependent anabolic processes. A very important general view was proposed by Wilson (1968) suggesting that a change in soluble-particulate distribution could be a factor in regulation of hexokinase activity in vivo.

We have previously shown (Bustamante \& Pedersen, 1977) that the rapidly proliferating rat hepatoma cell line H-91 established in this laboratory falls in the class of tumors that are highly glycolytic under aerobic conditions (Warburg effect). Additionally, we showed that these hepatoma cells exhibit high rates of lactic acid production only when grown in a medium containing a hexose that is a substrate for hexokinase (Bustamante \& Pedersen, 1977; Bustamante et al., 1978). When grown in a medium containing a hexose that can be phosphorylated but which is not a substrate for hexokinase, H-91 hepatoma cells exhibit rates of aerobic lactic acid production nearing those of normal liver. Significantly, the hexokinase activity of these cells was found to be elevated relative to normal controls, and about $50 \%$ of it was found to be mitochondrially bound (Bustamante \& Pedersen, 1977). Thus, results from past work in this laboratory suggested that mitochondrially bound hexokinase might be responsible, at least in part, for the high aerobic glycolysis typical of some tumor cells.

The experimental work described in this study was undertaken to obtain information that would give better insight into the nature of the binding of hexokinase to hepatoma mitochondria. Specifically, experiments were carried out to answer the following questions: (a) What agents release the enzyme from hepatoma mitochondria? (b) Is enzyme binding to the membrane dependent on energization of mitochondria? (c) Do the kinetic properties of the mitochondrially bound hexokinase differ from those of the solubilized form of the enzyme and from those of the hexokinase localized in the cytosol? Experimental results which provide answers to these questions are summarized in detail below.

Experimental Procedure

\section{Materials}

Tissue culture reagents were purchased from Microbiological Associates, Inc. Glucose-6-phosphate dehydrogenase was from Boehringer-Mannheim. ATP, ADP, AMP, ITP, and $\mathrm{NADP}^{+}$were obtained from P-L Biochemicals. AMP-PNP ${ }^{1}$

\footnotetext{
${ }^{1}$ Abbreviations used: AMP-PNP, adenyl-5'-yl imidodiphosphate; Hepes, 4-(2-hydroxyethyl)-1-piperazineethanesulfonic acid; FCCP, carbonyl cyanide $p$-(trifluoromethoxy)phenylhydrazone; ATP, adenosine 5'-triphosphate; ADP, adenosine 5'-diphosphate; AMP, adenosine 5'monophosphate; NADP, nicotinamide adenine dinucleotide phosphate; NADPH, reduced NADP; EDTA, ethylenediaminetetraacetic acid.
}

was purchased from ICN Pharmaceuticals. Glucose, glucose 6-phosphate, oligomycin, and atractyloside were obtained from Sigma Chemical Co. Sucrose was from Baker, and Hepes was from Calbiochem. FCCP was generously donated by Dr. P. G. Heytler of Du Pont.

\section{Methods}

Cell Line and Tissue Culture. The cell line H-91 was established originally in this laboratory (Bustamante \& Pedersen, 1977) from the chemically induced rat ascites hepatoma AS-30D (Smith et al., 1970). H-91 cells were routinely grown at $37^{\circ} \mathrm{C}$ in closed Falcon flasks made of sulfonated polystyrene by using L-15 Leibovitz medium (Leibovitz, 1963) supplemented with $5 \%(\mathrm{v} / \mathrm{v})$ fetal bovine serum (heat inactivated) and $0.1 \mathrm{mg} / \mathrm{mL}$ gentamicin, at $\mathrm{pH} 7.4$ and under a $100 \%$ air atmosphere. The cells were transferred every 5-6 days from one into four or five flasks by using $0.25 \%(w / v)$ trypsin in an isotonic medium as a detaching agent.

Cell Fractionation. H-91 cells were removed from flasks with a trypsin solution as described above and suspended in complete growth medium to stop further trypsin action (the $5 \%$ fetal bovine serum in the medium contains a trypsin inhibitor). The cells were then centrifuged at $700 \mathrm{rpm}$ in an International centrifuge for $3 \mathrm{~min}$ at $25^{\circ} \mathrm{C}$ and resuspended in a medium containing $250 \mathrm{mM}$ sucrose and $30 \mathrm{mM}$ Hepes, $\mathrm{pH} 7.4$. This washing procedure was repeated at least 2 additional times with the latter suspension medium. The final cell sediment was suspended at a density of $\sim 5 \times 10^{7}$ cells $/ \mathrm{mL}$ in volumes smaller than $5 \mathrm{~mL}$. The cell suspension was homogenized by sonic oscillation for $15 \mathrm{~s}$ at $0-4{ }^{\circ} \mathrm{C}$ with the small probe of a Bronwill Biosonik sonic oscillation apparatus at $20 \%$ output. All subsequent operations were performed at $0-4{ }^{\circ} \mathrm{C}$. The cell homogenate, which typically consisted of $90 \%$ disrupted cells, was centrifuged at $770 \mathrm{~g}$ for $5 \mathrm{~min}$ in a Sorvall RC-2B centrifuge. The sediment was discarded, and the supernatant was centrifuged at $7900 \mathrm{~g}$ for $10 \mathrm{~min}$ in a Sorvall rotor. The supernatant was saved and will be referred to as the postmitochondrial fraction. The sediment was resuspended in $250 \mathrm{mM}$ sucrose and $30 \mathrm{mM}$ Hepes, $\mathrm{pH} 7.4$, and centrifuged at $7900 \mathrm{~g}$ for $10 \mathrm{~min}$ in a Sorvall rotor. The resulting supernatant was discarded, and the sediment (mitochondrial fraction) was resuspended in a minimum volume of $250 \mathrm{mM}$ sucrose and $30 \mathrm{mM}$ Hepes, $\mathrm{pH} \mathrm{7.4}$. The postmitochondrial fraction was centrifuged at $48000 \mathrm{rpm}(150000 \mathrm{~g}$ average) for $45 \mathrm{~min}$ in a Beckman Type 65 rotor at $4^{\circ} \mathrm{C}$. The resulting sediment was discarded, and the supernatant was dialyzed overnight at $4{ }^{\circ} \mathrm{C}$ against $4 \mathrm{~L}$ of $250 \mathrm{mM}$ sucrose and $30 \mathrm{mM}$ Hepes, $\mathrm{pH}$ 7.4. The resulting dialyzate is referred to as the cytosolic fraction.

The mitochondrial fraction prepared as described above exhibited acceptor control ratios between 4 and 6 with succinate as substrate and was found on this basis to be as intact as control liver mitochondria [see Bustamante \& Pedersen (1977)].

Determination of Hexokinase Activity. Hexokinase (EC 2.7.1.1) activity was determined spectrophotometrically by a modification of the procedure of Slein (1957) by following the rate of formation of NADPH at $340 \mathrm{~nm}$ in a $1-\mathrm{mL}$ system containing $32 \mathrm{mM}$ Hepes, $12 \mathrm{mM} \mathrm{MgCl}_{2}, 6.5 \mathrm{mM}$ ATP, 0.9 $\mathrm{mM}$ NADP $^{+}, 1$ unit of glucose-6-phosphate dehydrogenase, and $0.5 \mathrm{mM}$ glucose, at $\mathrm{pH} 7.6$ and $25^{\circ} \mathrm{C}$.

Solubilization of Mitochondrial Hexokinase. Except where otherwise indicated, the agent used for solubilizing (or releasing) hexokinase from the mitochondria was $10 \mathrm{mM}$ ATP (free of $\mathrm{Mg}$ ions). The solubilization process was carried out as follows: hepatoma mitochondria $(30-50 \mu \mathrm{g}$ in analytical 
Table I: Efficacy of Various Agents in Solubilizing Mitochondrial Hexokinase ${ }^{a}$

\begin{tabular}{|c|c|c|c|}
\hline $\begin{array}{c}\text { expt } \\
\text { no. }\end{array}$ & & $\begin{array}{l}\text { hexokinase } \\
\text { act. bound } \\
\text { (nmol of } \\
\text { glucose/min) }\end{array}$ & $\begin{array}{c}\% \\
\text { bound }\end{array}$ \\
\hline 1 & $\begin{array}{l}\text { control } \\
4 \mathrm{mM} \mathrm{ATP} \\
10 \mathrm{mM} \text { ATP } \\
10 \mathrm{mM} \text { AMP-PNP } \\
10 \mathrm{mM} \mathrm{ADP} \\
10 \mathrm{mM} \mathrm{AMP} \\
10 \mathrm{mM} \mathrm{ITP} \\
10 \mathrm{mM} \mathrm{KP} \\
2 \mathrm{mM} \mathrm{Glc}-6-\mathrm{P} \\
10 \mathrm{mM} \mathrm{EDTA} \\
100 \mathrm{mM} \mathrm{NaCl} \\
1 \mathrm{M} \mathrm{NaCl}\end{array}$ & $\begin{array}{r}12.6 \\
6.4 \\
3.5 \\
7.7 \\
10.3 \\
11.6 \\
7.6 \\
11.8 \\
5.9 \\
12.6 \\
12.3 \\
1.6\end{array}$ & $\begin{array}{c}(100) \\
50 \\
28 \\
61 \\
82 \\
92 \\
60 \\
94 \\
47 \\
100 \\
98 \\
13\end{array}$ \\
\hline 2 & $\begin{array}{l}\text { control } \\
10 \mathrm{mM} \text { ATP } \\
10 \mathrm{mM} \text { EDTA } \\
10 \mathrm{mM} \text { ATP } \\
\text { plus } 10 \mathrm{mM} \mathrm{MgCl} \\
10 \mathrm{mM} \text { ATP } \\
\text { plus } 10 \mathrm{mM} \mathrm{MgCl} \\
\text { plus } 10 \mathrm{mM} \mathrm{EDTA}\end{array}$ & $\begin{array}{r}9.8 \\
4.7 \\
10.0 \\
10.2 \\
4.7\end{array}$ & $\begin{array}{r}(100) \\
48 \\
102 \\
104 \\
48\end{array}$ \\
\hline
\end{tabular}

${ }^{a}$ Mitochondria were isolated from H-91 cell homogenates as described under Methods in a medium containing $250 \mathrm{mM}$ sucrose and $30 \mathrm{mM}$ Hepes, $\mathrm{pH} 7.4$. H-91 hepatoma mitochondria (43 $\mu \mathrm{g}$ ) were placed in tubes containing $1 \mathrm{~mL}$ (final volume) of homogenization medium with the additions listed above. The tubes were incubated for $10 \mathrm{~min}$ at $25^{\circ} \mathrm{C}$. Mitochondrial sediments were collected by centrifugation at $10000 \mathrm{~g}$ for $10 \mathrm{~min}$ at $4^{\circ} \mathrm{C}$ in a Sorvall rotor. The sediments were quantitatively resuspended in homogenzation medium and transferred to cuvettes containing the assay mixture for the hexokinase assay (see Methods). Hexokinase activities above represent averages of duplicate determinations. Although activities are expressible as percent hexokinase bound, it is important to note that the remaining part of the total activity was recoverable in the superna$\operatorname{tant}$

experiments, more in preparative experiments) were incubated in a final volume of $1 \mathrm{~mL}$, in a medium containing the releasing agent, $250 \mathrm{mM}$ sucrose, and $30 \mathrm{mM}$ Hepes, $\mathrm{pH} 7.4$, for $10 \mathrm{~min}$ at $25^{\circ} \mathrm{C}$. Subsequently, mitochondrial sediments were collected by centrifugation at $10000 \mathrm{~g}$ for $10 \mathrm{~min}$ at $4^{\circ} \mathrm{C}$ in a Sorvall rotor. When analytical experiments were carried out, the sediments were quantitatively resuspended in small

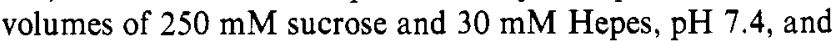
transferred completely to cuvettes containing the mixtures for assaying hexokinase activity as described above. When solubilized mitochondrial hexokinase was prepared, the supernatant resulting from the above centrifugation was dialyzed against $4 \mathrm{~L}$ of $250 \mathrm{mM}$ sucrose and $30 \mathrm{mM}$ Hepes, $\mathrm{pH} 7.4$. The resulting dialyzate constitutes what is referred to as solubilized mitochondrial hexokinase.

Determination of Protein. Interfering solutes were removed by precipitation with $5 \%$ trichloroacetic acid, and the resulting precipitate was sedimented at $18000 \mathrm{~g}$ for $20 \mathrm{~min}$ at $4^{\circ} \mathrm{C}$ in a Sorvall rotor. The resulting sediments were alkalinized with $1 \mathrm{~N} \mathrm{NaOH}$ and constituted the samples for determination of protein by the procedure of Lowry et a1. (1951).

\section{Results}

Release of Hexokinase Bound to Mitochondria. Rose \& Warms (1967) showed that hexokinase bound to the mitochondria of sarcoma tissue can be released rather specifically from the outer mitochondrial membrane via the action of compounds such as ATP and glucose 6-phosphate. Data summarized in Table I show that ATP and glucose 6-phos-
Table II: Partial Purification of Mitochondrial Hexokinase by Solubilization with ATP ${ }^{a}$

\begin{tabular}{|c|c|c|c|c|}
\hline & $\begin{array}{l}\text { (nmol of } \\
\text { glucose/ } \\
\text { min) }\end{array}$ & $\begin{array}{l}\text { protein } \\
\text { (mg) }\end{array}$ & $\begin{array}{c}\text { sp act. } \\
\text { [nmol/(min } \\
\text { mg of } \\
\text { protein)] }\end{array}$ & $\begin{array}{c}\% \\
\text { yield }\end{array}$ \\
\hline & & & 198 & $(100)$ \\
\hline $\begin{array}{l}\text { solubilized } \\
\text { hexokinase }\end{array}$ & 499 & 0.39 & 1279 & 78 \\
\hline \multicolumn{5}{|c|}{$\begin{array}{l}\text { a Mitochondria were isolated from H-91 hepatoma cells as de- } \\
\text { scribed under Methods in a medium containing } 250 \mathrm{mM} \text { sucrose } \\
\text { and } 30 \mathrm{mM} \text { Hepes, pH } 7.4 \text {. Mitochondrial hexokinase was solu- } \\
\text { bilized with } 10 \mathrm{mM} \text { ATP in the above medium. Incubation time } \\
\text { was } 10 \mathrm{~min} \text { at } 25^{\circ} \mathrm{C} \text {. The mixtures were subsequently centrifuged } \\
\text { at } 10000 \mathrm{~g} \text { for } 10 \mathrm{~min} \text { at } 4{ }^{\circ} \mathrm{C} \text { in a Sorvall rotor. The sediments } \\
\text { were discarded, and the supernatants were assayed for hexokinase } \\
\text { activity as described under Methods. Results shown are the aver- } \\
\text { ages of duplicate determinations. }\end{array}$} \\
\hline
\end{tabular}

phate are effective agents for solubilizing mitochondrial hexokinase of $\mathrm{H}-91$ hepatoma cells. Equimolar concentrations of other nucleotides are not as effective as ATP, whereas phosphate seems to be ineffective in releasing the enzyme. In addition, results presented in Table I show that EDTA concentrations less than or equal to $10 \mathrm{mM}$ are completely ineffective in releasing hexokinase from the mitochondria of H-91 cells. This finding tends to rule out the possibility that the solubilizing effect of ATP might be due to chelation of a putative divalent cation essential for binding to the membrane. The bound mitochondrial hexokinase is resistant to relatively high ionic strength as evidenced by the lack of a releasing action by $0.1 \mathrm{M} \mathrm{NaCl}$. Although $1 \mathrm{M} \mathrm{NaCl}$ is able to release mitochondrial hexokinase, it probably involves a very nonspecific mechanism due to the excessively high ionic strength.

Data summarized in Table I also show that free (uncomplexed by $\mathrm{Mg}$ ions) ATP is the true releasing agent for hepatoma mitochondrial hexokinase. When ATP is present in the MgATP form, there is no release of hexokinase. However, the chelator EDTA, which by itself is unable to release the enzyme, appears to effectively compete with ATP in complexing $\mathrm{Mg}$ ions, thus freeing ATP and apparently rendering it fully active as a releasing agent. EDTA binds $\mathrm{Mg}^{2+}$ with greater affinity than ATP binds $\mathrm{Mg}^{2+}$ at $\mathrm{pH}$ values between 7 and 8 (Dawson et al., 1969).

Table II shows that the release of hexokinase from the mitochondria by $10 \mathrm{mM}$ ATP results in a sixfold increase in specific activity. Typically, a six- to sevenfold increase in specific activity is observed upon ATP solubilization with a yield of $70-80 \%$.

Energy Requirements for Release of Mitochondrial Hexokinase. The specific need for the triphosphate form, ATP, raised the possibility that ATP might be hydrolyzed during the process of release of hexokinase from the outer mitochondrial membrane. Table I shows that the nonhydrolyzable ATP analogue AMP-PNP is also effective at $10 \mathrm{mM}$ final concentration as a releasing agent for mitochondrial hexokinase. This strongly suggests that ATP hydrolysis is not essential for the release of mitochondrial hexokinase and also shows that the enzyme recognizes ATP with great specificity. Thus, it was of interest to determine if perhaps other mitochondrial sources of free energy could be responsible for such action. Table III shows that the uncoupler of oxidative phosphorylation FCCP can neither release hexokinase from the membrane nor prevent ATP from releasing it. In addition, the inhibitor of nucleotide translocation $\left(\mathrm{ATP}^{4-} / \mathrm{ADP}^{3--}\right.$ antiport), atractyloside, and the inhibitor of oxidative phospho- 
Table III: Energy Independence of Solubilization by ATP of Hepatoma Mitochondrial Hexokinase ${ }^{a}$

\begin{tabular}{|c|c|c|}
\hline & $\begin{array}{l}\text { hexokinase } \\
\text { act. bound } \\
\text { (nmol of } \\
\text { glucose/min) }\end{array}$ & $\begin{array}{c}\% \\
\text { bound }\end{array}$ \\
\hline control & 9.2 & $(100)$ \\
\hline $10 \mathrm{mM}$ ATP & 4.5 & $49^{\prime}$ \\
\hline $10 \mu \mathrm{M} \mathrm{FCCP}$ & 9.4 & 102 \\
\hline $\begin{array}{l}10 \mathrm{mM} \mathrm{ATP} \\
\text { plus } 10 \mu \mathrm{M} \text { FCCP }\end{array}$ & 4.4 & 48 \\
\hline $\begin{array}{l}10 \mathrm{mM} \mathrm{ATP} \\
\text { plus } 15 \mu \mathrm{M} \text { atractyloside }\end{array}$ & 4.8 & 52 \\
\hline $\begin{array}{l}10 \mathrm{mM} \text { ATP } \\
\text { plus } 10 \mu \mathrm{g} / \mathrm{mL} \text { oligomycin }\end{array}$ & 4.5 & 49 \\
\hline $\begin{array}{l}10 \mathrm{mM} \text { ATP } \\
\text { plus } 10 \mathrm{mM} \mathrm{MgCl}\end{array}$ & 9.3 & 101 \\
\hline
\end{tabular}

${ }^{a}$ Mitochondria from H-91 cells were isolated according to the procedure described under Methods in a medium containing 250 $\mathrm{mM}$ sucrose and $30 \mathrm{mM}$ Hepes, $\mathrm{pH} 7.4 .42 \mu \mathrm{g}$ of hepatoma mitochondria per assay were processed as described in the legend to Table I. Hexokinase activity bound was determined in the resulting sediments as described under Methods. Results shown are the averages of triplicate determinations.

rylation, oligomycin, are also without effect in preventing ATP from releasing hexokinase from the outer mitochondrial membrane. Moreover, it should be pointed out that both oligomycin and atractyloside are by themselves unable to solubilize mitochondrial hexokinase (data not shown).

These results indicate that energization of mitochondria (either through ATPase, ATP translocation, or an electrochemical gradient) is not required for the release of hexokinase by ATP.

Kinetic Properties of the Subcellular Forms of Hexokinase. Since Rose \& Warms (1967) first postulated a potential physiological role for the release of hexokinase from the mitochondria and rebinding to these organelles, it was of interest to determine whether kinetic differences existed between the bound and solubilized forms of the mitochondrial hexokinase relative to hexokinase activity typically found in the cytosolic fraction.

Figure 1 (left) shows Lineweaver-Burk plots of hexokinase activity as a function of glucose concentration. ATP was 6.5 $\mathrm{mM}$. Figure 1 (right) shows Lineweaver-Burk plots of hexokinase activity as a function of ATP concentration at saturating $\mathrm{Mg}^{2+}$ concentration (thus ensuring complete formation of the MgATP complex). Glucose was $0.5 \mathrm{mM}$. Total $\mathrm{Mg}^{2+}$ was kept constant at $12 \mathrm{mM}$ and ATP was varied. Thus, free $\mathrm{Mg}^{2+}$ concentration was also varying. In control experiments free $\mathrm{Mg}^{2+}$ had no effect on hexokinase activity. In assays of mitochondrially bound hexokinase the enzyme remained bound to the membrane during the assay. Thus, when the assay system was centrifuged at $10000 \mathrm{~g}$ for $10 \mathrm{~min}$, essentially all of the hexokinase activity was recovered in the sediment.

The apparent $K_{\mathrm{m}}$ 's (glucose) for the three hexokinase forms studied are essentially identical $(56-83 \mu \mathrm{M})$ and within experimental error. On the other hand, the apparent $K_{\mathrm{m}}$ (MgATP) of the bound form of mitochondrial hexokinase is about 5 times lower than that of the solubilized form of the enzyme. Significantly, the apparent $K_{\mathrm{m}}$ (MgATP) of the hexokinase activity found in the cytosol is identical with that of the bound mitochondrial enzyme. Nevertheless, it is interesting to note the difference in apparent affinity for MgATP of the solubilized mitochondrial enzyme relative to the cytosolic hexokinase.

Thus, H-91 hepatoma cells appear to have two kinetically different forms of mitochondrial hexokinase. The mitochon-

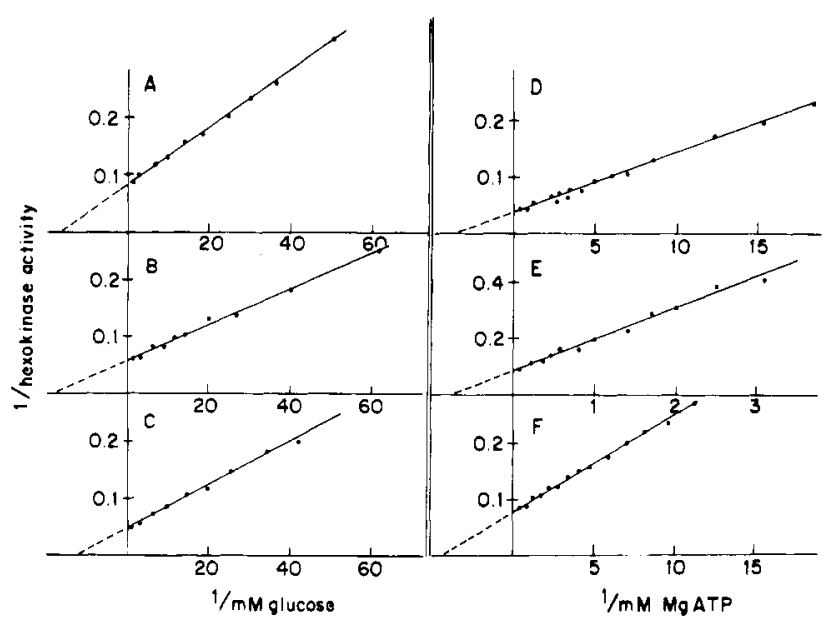

FIGURE 1: Lineweaver-Burk plots of dependence of hepatoma hexokinase on glucose (left panel) and MgATP (right panel). (A, D) Mitochondrially bound hexokinase. Mitochondria from $\mathrm{H}-91$ hepatoma cells were prepared as described under Methods and assayed for hexokinase activity at indicated substrate concentrations. (B, E) Solubilized mitochondrial hexokinase. Mitochondrial hexokinase was solubilized from $\mathrm{H}-91$ mitochondria with $10 \mathrm{mM}$ ATP as described in the legend to Table II. It was subsequently dialyzed against 4000 volumes (two changes) of $250 \mathrm{mM}$ sucrose and $30 \mathrm{mM}$ Hepes, $\mathrm{pH}$ 7.4 , at $4{ }^{\circ} \mathrm{C}$ to eliminate the ATP present. (C, F) Cytosolic hexokinase. The postmitochondrial fraction (see Methods) was centrifuged at $150000 \mathrm{~g}$ for $45 \mathrm{~min}$ at $4^{\circ} \mathrm{C}$ in the Beckman Type 65 rotor. The resulting supernatant was concentrated in dialysis bags against solid sucrose and then dialyzed against 2000 volumes (two changes) of 250 $\mathrm{mM}$ sucrose and $30 \mathrm{mM}$ Hepes, $\mathrm{pH} \mathrm{7.4.} \mathrm{All} \mathrm{activities} \mathrm{are} \mathrm{expressed}$ in nmol of glucose per min. See Methods for assay details. In all cases the $\mathrm{MgCl}_{2}$ concentration always exceeded that of ATP in the assay.

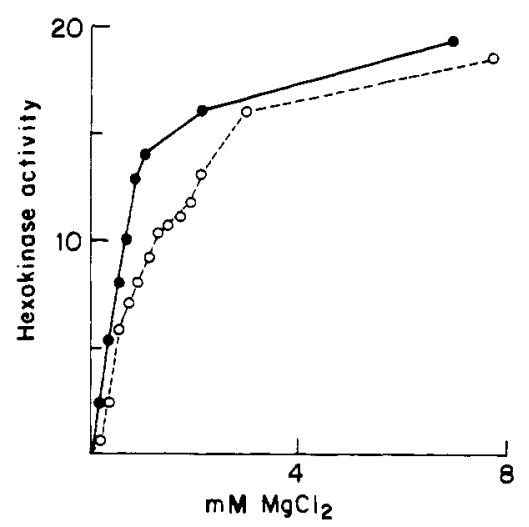

FIGURE 2: Dependence of mitochondrially bound hexokinase activity on $\mathrm{Mg}^{2+}$ concentration as a function of ATP concentration. Mitochondria were isolated from $\mathrm{H}-91$ hepatoma homogenates as described under Methods in a medium containing $250 \mathrm{mM}$ sucrose and $30 \mathrm{mM}$ Hepes, $\mathrm{pH}$ 7.4. The concentrations of $\mathrm{MgCl}_{2}$ shown were determined by atomic absorption spectrometry. See Methods for assay details. (e) $3 \mathrm{mM}$ ATP; (O) $12 \mathrm{mM}$ ATP.

drial form can bind to or be released from mitochondria, presumably according to metabolic conditions. When bound to the mitochondria, this enzyme has a higher apparent affinity for MgATP than when solubilized.

Figure 2 shows the dependence of bound mitochondrial hexokinase activity on $\mathrm{Mg}^{2+}$ concentration, at two different ATP concentrations. Significantly, a higher concentration of total ATP yields a curve which is displaced to the right. Thus, increasing the total ATP concentration over the same $\mathbf{M g}^{2+}$ concentration range appears to be inhibitory for the hexokinase reaction. In order to clarify this point, the true concentrations of MgATP complex were calculated for each data point. This was done by using the stability constant for the formation of the MgATP complex $\left(K_{\mathrm{s}}=20 \mathrm{mM}^{-1}\right)$ described by O'Sullivan 


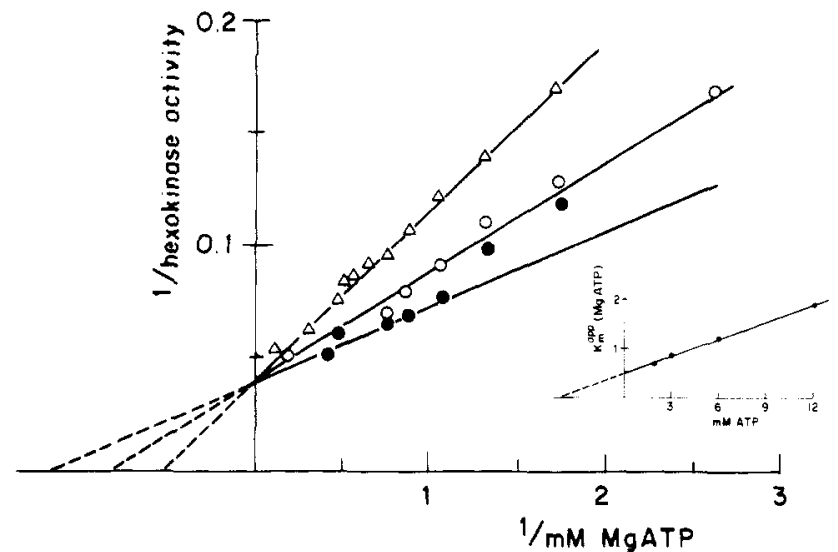

FIGURE 3: Lineweaver-Burk plots of dependence of mitochondrially bound hexokinase activity on MgATP concentration as a function of total ATP. Mitochondria were prepared from $\mathrm{H}-91$ hepatoma homogenates as described under Methods. The data were extracted from curves similar to those depicted in the figure. True MgATP concentrations were calculated by using the stability constant for the formation of the MgATP complex $\left(K_{s}=20 \mathrm{mM}^{-1}\right)$ described by O'Sullivan \& Perrin (1961). See Methods for assay details. (O) 3 mM ATP; (O) $5 \mathrm{mM} \mathrm{ATP;} \mathrm{( \triangle )} 12 \mathrm{mM} \mathrm{ATP.} \mathrm{(Inset)} \mathrm{Dependence}$ of the apparent $K_{\mathrm{m}}$ (MgATP) on the concentration of free ATP. The data were extracted from curves similar to those depicted in the figure. The apparent $K_{m}$ 's at each ATP concentration were taken from the figure and plotted as a function of ATP concentration. Thus, the following kinetic equation was satisfied: intercept $=[\mathrm{ATP}] K_{\mathrm{m}} / K_{\mathrm{i}}$ $+K_{\mathrm{m}}$. Consequently, the intercept on the ordinate yields the "true" $K_{\mathrm{m}}$ (MgATP), and the intercept on the abscissa yields the $K_{\mathrm{i}}(\mathrm{ATP})$. See Methods for assay details.

\& Perrin (1961). These values were plotted as LineweaverBurk reciprocals as a function of total ATP concentration (Figure 3). This figure clearly depicts that free ATP behaves as a competitive inhibitor with the true substrate MgATP. This is more clearly seen in the inset to Figure 3, where the apparent $K_{\mathrm{m}}$ 's for MgATP are plotted as a function of each total ATP concentration. The $K_{\mathrm{i}}$ (ATP) obtained from this plot is $\sim 4 \mathrm{mM}$, a value remarkably similar to the concentration needed to release $50 \%$ of the enzyme from mitochondria (Table I). Extrapolation to zero ATP concentration yields an apparent $K_{\mathrm{m}}$ (MgATP) value of $\sim 0.4 \mathrm{mM}$. Interestingly, this number is within the same order of magnitude as the apparent $K_{\mathrm{m}}$ (MgATP) value determined directly $(0.25 \mathrm{mM} \mathrm{MgATP})$ from data in Figure 1 for the bound mitochondrial hexokinase.

\section{Discussion}

Results presented in this paper summarize the first detailed study of a form of hexokinase bound to the mitochondria of a highly glycolytic hepatoma. The properties of the enzyme as well as the nature of the binding to the membrane are experimental questions of special interest since liver has little or no hexokinase (not to be confused with the high $K_{\mathrm{m}}$ enzyme glucokinase, EC 2.7.1.2) activity associated with its hepatocyte populations (Morrison, 1967; Crisp \& Pogson, 1972; SapagHagar et al., 1969). Thus, the synthesis (or activation) of the enzyme in H-91 cells, a hepatocellular carcinoma cell type (Smith et al., 1970), must not only have been induced upon neoplastic transformation but in addition become associated with the cell mitochondria.

Prior results from this laboratory (Bustamante \& Pedersen, 1977) have strongly suggested that mitochondrial hexokinase of $\mathrm{H}-91$ hepatoma cells is responsible, at least partially, for their high aerobic glycolytic rate. However, it is not clear as yet just how mitochondrial hexokinase might effect such a role, despite the many observations that link tumor mitochondria to the efficiency of glycolytic systems [Weinhouse, 1966;
Wenner, 1967; Lo et al., 1968; Colowick \& Nagarajan, 1972; Bustamante et al, 1978; for a recent review, see also Pedersen (1978)]. With these thoughts in mind, the primary purpose of this work was to try to better understand how hepatoma hexokinase is associated with mitochondria. Work described in this paper deals specifically with some molecular properties of the enzyme with respect to conditions for its release and energy requirements for such release, as well as the differential kinetic parameters of the subcellular forms of the enzyme.

Experimental results presented here show that the association of hexokinase with mitochondria from hepatoma cells is rather specific. Such specificity is illustrated by the fact that the reactants ATP and glucose 6-phosphate promote the release of the enzyme from mitochondria, while other nucleotides or phosphate compounds are either ineffective or not as effective. These results are similar to those reported earlier by Rose \& Warms (1967) working with mitochondrial hexokinase of sarcoma tissue and similar to work by other investigators working with mitochondrial hexokinase of other sources [see Wilson \& Flegner (1977) for a review].

It should be pointed out that the form of ATP capable of solubilizing hexokinase is most likely that which is unchelated by $\mathrm{Mg}$ ions; the MgATP complex is unable to release the enzyme (Table I). Significantly, EDTA was unable to release the enzyme from mitochondria. This observation tends to rule out the possibility that hexokinase might bind to mitochondria via a hitherto unidentified membrane-bound divalent cation susceptible to chelation by ATP. It is interesting to mention at this point that an integral protein has been isolated recently from the outer membrane of rat liver mitochondria. This protein may be responsible for the selective binding of hexokinase by mitochondria (Felgner et al., 1979). Conceivably, hepatoma hexokinase might well bind to tumor mitochondria via a similar membrane protein. It is interesting to note also that although Rose \& Warms (1967) suggested that hexokinase may be bound to sarcoma mitochondria via $\mathrm{Mg}^{2+}$ ions, they did not rule out the possibility that hydrophobic forces might be involved as well. This was because high salt concentrations did not promote elution at $\mathrm{pH} 8.0$.

It is perhaps important to note that ATP does not release a protein with a specific activity characteristic of a pure hexokinase. The ATP-released enzyme is purified sixfold relative to the membrane-bound enzyme, but in released form its specific activity is only $1.3 \mu \mathrm{mol} \mathrm{min} \mathrm{mg}^{-1} \mathrm{mg}^{-1}$. This observation would suggest that ATP induces the release of other membrane proteins together with hexokinase or that a regulator molecule is bound to the enzyme and maintains it in a low specific activity state. Extensions of these studies should prove to be an interesting line of study in future work.

Additional experiments reported in this paper indicate that hepatoma mitochondrial hexokinase when membrane bound has a significantly higher apparent affinity for MgATP than when solubilized. On the other hand, the apparent affinity for the other substrate, glucose, is similarly high for both forms of the enzyme. These findings differ from those reported by Kosow \& Rose (1968) who found very little difference in kinetic constants between bound and unbound forms of mitochondrial hexokinase of sarcoma tissue.

It is noteworthy that the apparent $K_{\mathrm{m}}$ (MgATP) of the cytosolic hexokinase is identical with that of the bound form of mitochondrial hexokinase. One interpretation of the latter observation is that the enzyme activity found in the cytosolic fraction of $\mathrm{H}-91$ cells may represent hexokinase bound to mitochondrial fragments (perhaps formed during sonication of cells) which do not sediment at $150000 \mathrm{~g}$. However, at this 
time we have no evidence that small mitochondrial fragments containing bound hexokinase are present in the postmitochondrial supernatant.

Significantly, results reported here show that free ATP is a rather potent $\left(K_{\mathrm{i}}=4 \mathrm{mM}\right)$ competitive inhibitor of the reaction (see Figures 2 and 3 ) in addition to being a specific agent for releasing the mitochondrially bound enzyme (see Table I). Fromm and co-workers (Ning et al., 1969) have shown that free ATP is a competitive inhibitor of brain hexokinase also. It is interesting to note (see Table I) that the concentration of free ATP required to release half of the mitochondrially bound form of hexokinase ( $4 \mathrm{mM} \mathrm{ATP})$ is identical with that required to inhibit half of the enzyme activity. Free ATP is able to release hexokinase from the membrane, and in so doing it generates an enzyme form which has a lower apparent affinity for its substrate MgATP. A kinetic analysis of the effect of free ATP on the membranebound form of the enzyme, such as that carried out here, would be predicted to yield an inhibition pattern of the competitive type (where the apparent $K_{\mathrm{m}}$ varies). Significantly, results presented here show such an inhibition pattern.

The recent finding of Womack \& Colowick (1979) that an $\mathrm{Al}^{3+}$ impurity in commercial ATP inhibited yeast hexokinase P-11 merits some discussion because it could be argued that the results in Figures 2 and 3 are influenced by this impurity. However, it should be noted that at $\mathrm{pH} 7.6$, the $\mathrm{pH}$ of the assay used in this study, $\mathrm{Al}^{3+}$ was essentially without effect on yeast hexokinase. The apparent $\mathrm{Al}^{3+}$ inhibitory effect is strongly $\mathrm{pH}$ dependent with maximal inhibition occurring below $\mathrm{pH}$ 7.0 .

The results presented here suggest that the intracellular distribution of hepatoma mitochondrial hexokinase may reflect an expression of the metabolic state of the cancer cell. Thus, the binding of hexokinase to the mitochondria might reflect a need by the hepatoma cell to increase the affinity of hexokinase for MgATP as well as to perhaps gain preferential access to mitochondrially generated ATP. This is consistent with the proposal by Wilson (1968) for brain hexokinase and the results obtained by others also in brain tissue (Knull et al., 1974; Bachelard, 1976). However, in the study of Kopelovich et al. (1966) no evidence was found that the carcinogenic state involved a change in the intracellular location of hexokinase.

Clearly, further experimental work is necessary to establish whether free or bound forms of mitochondrial hexokinase (or both forms) play a role in the maintenance of the neoplastic state. In studies to be presented elsewhere we will show that only those tumor cells with an elevated glycolytic rate have mitochondrially associated hexokinase. Currently, studies are in progress to better understand the binding and release phenomenon of the enzyme in tumor mitochondria.

\section{References}

Asc, G., Garzo, T., Grosz, G., Molnar, J., Stephaneck, O., \& Straub, F. B. (1955) Acta Physiol. Acad. Sci. Hung. 8, 269-278.

Bachelard, H. S. (1976) in Biochemistry and Neurological Disease (Davidson, A. N., Ed.) pp 228-277, Blackwell, London.

Bessman, S. P. (1966) Am. J. Med. 40, 740-749.

Bessman, S. P., Borrebaek, B., Geiger, P. J., \& Ben-Or, S. (1978) in Microenviron. Metab. Compartmentation [Vir- ginia Lazenby O'Hara Biochem. Symp.], 111-126.

Bustamante, E., \& Pedersen, P. L. (1977) Proc. Natl. Acad. Sci. U.S.A. 74, 3735-3739.

Bustamante, E., Morris, H. P., \& Pedersen, P. L. (1978) Adv. Exp. Med. Biol. 92, 363-380.

Colowick, S. P. (1973) Enzymes, 3rd Ed. 9, 1-48.

Colowick, S. P., \& Nagarajan, B. (1972) in Horizons of Bioenergetics (San Pietro, A., \& Gest, H., Eds.) pp 97-112, Academic Press, New York.

Crane, R. K., \& Sols, A. (1953) J. Biol. Chem. 203, 273-292.

Crisp, D. M., \& Pogson, C. I. (1972) Biochem. J. 126, 1009-1023.

Dawson, R. M. C., Elliot, D. C., Elliott, W. H., \& Jones, K. M. (1969) Data for Biochemical Research, 2nd ed., pp 423-434, Oxford University Press, London.

Felgner, P. L., Messer, J. L., \& Wilson, J. E. (1979) J. Biol. Chem. 254, 4946-4949.

Gellerich, F. N., \& Augustin, H. W. (1977) Acta Biol. Med. Ger. 36, 571-577.

Gots, R. E., \& Bessman, S. P. (1974) Arch. Biochem. Biophys. $163,7-14$.

Graziani, Y. (1977) Biochim. Biophys. Acta 460, 363-373.

Hernandez, A., \& Crane, R. K. (1966) Arch. Biochem. Biophys. 113, 223-229.

Johnson, M. K. (1960) Biochem. J. 77, 610-618.

Knull, H. R., Taylor, W. F., \& Wells, W. W. (1974) J. Biol. Chem. 249, 6930-6935.

Koobs, D. H. (1971) Science 178, 127-133.

Kopelovich, L., Abraham, S., McGrath, H., DeOme, K. B., \& Chaikoff, I. L. (1966) Cancer Res. 26, 1534-1546.

Kosow, D. P., \& Rose, I. A. (1968) J. Biol. Chem. 243, 3623-3630.

Leibovitz, A. (1963) Am. J. Hyg. 78, 173-180.

Lo, C., Cristofalo, J., Morris, H. P., \& Weinhouse, S. (1968) Cancer Res. 28, 1-10.

Lowry, O., Rosebrough, N., Farr, A., \& Randall, R. (1951) J. Biol. Chem. 193, 265-275.

Morrison, G. R. (1967) Arch. Biochem. Biophys. 122, 569-573.

Ning, J., Purich, D. L., \& Fromm, H. H. (1969) J. Biol. Chem. 244, 3840-3846.

O'Sullivan, W. J., \& Perrin, D. D. (1961) Biochim. Biophys. Acta 52, 612-614.

Pedersen, P. L. (1978) Prog. Exp. Tumor Res. 22, 190-274.

Rose, I. A., \& Warms, J. V. B. (1967) J. Biol. Chem. 242, 1635-1645.

Sapag-Hagar, M., Marco, R., \& Sols, A. (1969) FEBS Lett. 3, 68-71.

Slein, M. W. (1957) Methods Enzymol. 3, 154-157.

Smith, D., Walborg, E., \& Chang, J. (1970) Cancer Res. 30, 2306-2309.

Utter, M. F., Wood, H. G., \& Reiner, J. M. (1945) J. Biol. Chem. 161, 191-217.

Weinhouse, S. (1966) Gann Monogr. 1, 99-114.

Wenner, C. E. (1967) Adv. Enzymol. Relat. Areas Mol. Biol. 29, 321-390.

Wilson, J. E. (1968) J. Biol. Chem. 243, 3640-3647.

Wilson, J. E., \& Flegner, P. L. (1977) Mol. Cell. Biochem. $18,39-47$.

Womack, F. C., \& Colowick, S. P. (1979) Proc. Natl. Acad. Sci. U.S.A. 76, 5080-5084.

Wu, R., \& Racker, E. (1959) J. Biol. Chem. 234, 1029-1035. 